\title{
High Temperature Millisecond Pyrolysis of Residue
}

\author{
Jinhong Zhang ${ }^{1, a}$, Yuanjun Che ${ }^{1, b}$, Yuanyu Tian $^{1, c}$, Yingyun Qiao $^{1, d}$ and Zhenbo
Wang $^{2, e}$ \\ ${ }^{1}$ State Key Laboratory of Heavy Oil Processing, China University of Petroleum, \\ Qingdao, Shandong, 266580, China \\ ${ }^{2}$ College of Chemical Engineering, China University of Petroleum, \\ Qingdao, Shandong, 266580, China \\ azjohn2004@163.com, ${ }^{b} 18795557511 @ 163 . c o m,{ }^{c}$ tianyy1008@126.com, \\ dqiao_yingyun@126.com, ${ }^{\mathrm{e}}$ wangzhb@upc.edu.cn
}

Keywords: High temperature, Fast pyrolysis, Residue.

Abstract. Due to the high boiling point of residue, hydrocarbons mainly occurred liquid-phase reactions in the delayed coking process. To enhance the gas-phase cracking of residues, the high temperature and short residence time processing scheme was performed in a Py-GC/TOF-MS apparatus. The residue was cracked at 600,700 and $800{ }^{\circ} \mathrm{C}$ in $200 \mathrm{~ms}$, and the variations of product compositions from $\mathrm{C}_{3}$ to $\mathrm{C}_{16}$ with pyrolysis temperature were analyzed. The results showed that the high-temperature and short-residence time operation favors production of olefins over paraffins. The most abundant classes are $\mathrm{C}_{5}$ and $\mathrm{C}_{6}$ both in olefins and paraffins.

\section{Introduction}

In view of the progressively increasing heavier nature of the crudes, the quantity of heavy residues is expected to increase in the future[1]. However, due to the characteristics of high boiling point, high contents of heteroatoms, and high coking tendency, it is difficult to process heavy residues in the catalytic cracking process. As the higher feed tolerance and lower processing cost, delayed coking becomes an important residue upgrading process in the current refining scenario, which is commonly operated at $400-500{ }^{\circ} \mathrm{C}[2]$. However, due to the boiling point of residue is mostly higher than $500{ }^{\circ} \mathrm{C}$, hydrocarbons mainly occurred liquid-phase reactions in the process. Wu et al.[3] compared the thermal cracking of $n$-hexadecane under liquid-phase and gas-phase conditions, and found that liquid-phase cracking gave a higher selectivity of addition compounds. Gray et al.[4] studied the thermal cracking of vacuum residue in a continuous flow aerosol reactor, and found that high-temperature and short-residence time is helpful to reducing coke yield, as more fraction of feed that would vaporize and react in the vapor phase. However, little work has been focused on the variation of detailed pyrolysis products. In this work, the effect of reaction temperature on the millisecond pyrolysis products of residue was investigated using Py-GC/TOF-MS.

\section{Experimental Section}

Feedstock. A residue provided by Shengli oil field (Shandong Province, China) was used as the heavy feedstock and its properties are shown in Table 1 . The residue has high density and viscosity. Moreover, the Conradson carbon residue (CCR) of the residue is up to approximately $16 \mathrm{wt} \%$.

Experimental Apparatus. The Py-GC/TOF-MS experiments were conducted by a Pyroprobe 5200 pyrolyser (CDS Analytical) with direct connection to a DANI gas chromatograph coupled to time of flight mass spectrometer. Each experiment was conducted with $0.400 \pm 0.005 \mathrm{mg}$ of oil sample in a quartz boat. An analytical balance with the readability of $0.001 \mathrm{mg}$ was used for weight, to ensure the accurate quantity of samples and residues. The pyrolysis was carried out at the set temperature from $600{ }^{\circ} \mathrm{C}$ to $800{ }^{\circ} \mathrm{C}$, at a heating rate of $2000{ }^{\circ} \mathrm{C} / \mathrm{s}$. The $\mathrm{GC}$ separation of pyrolysis vapors were done with a DB-5MS column $(60 \mathrm{~m} \times 0.25 \mathrm{~mm}, 0.25 \mu \mathrm{m}$ film thickness $)$ with Helium $(99.999 \%)$ carrier 
gas $(1 \mathrm{~mL} / \mathrm{min})$. The $\mathrm{GC}$ inlet was $280^{\circ} \mathrm{C}$ and a split ratio of $50: 1$ was used. The oven was programmed to start at $30{ }^{\circ} \mathrm{C}$ (hold for $15 \mathrm{~min}$ ) and then ramp at $1{ }^{\circ} \mathrm{C} / \mathrm{min}$ to $60{ }^{\circ} \mathrm{C}$ (hold for $1 \mathrm{~min}$ ), and then to $200{ }^{\circ} \mathrm{C}$ with the heating rate of $3{ }^{\circ} \mathrm{C} / \mathrm{min}$ followed by $10{ }^{\circ} \mathrm{C} / \mathrm{min}$ up to a final temperature of $280{ }^{\circ} \mathrm{C}$. The mass spectrometer was operated in EI mode at $70 \mathrm{eV}$, and the mass spectra were obtained from $\mathrm{m} / \mathrm{z} 35$ to 500. The chromatographic peaks were identified according to the NIST library.

Table 1. Properties of feedstock

\begin{tabular}{ccccccccc}
\hline $\begin{array}{c}\text { Density }\left(20^{\circ} \mathrm{C}\right) \\
{\left[\mathrm{kg} / \mathrm{m}^{3}\right]}\end{array}$ & $\begin{array}{c}\text { Viscosity }\left(100^{\circ} \mathrm{C}\right) \\
{\left[\mathrm{mm}^{2} \cdot \mathrm{s}^{-1}\right]}\end{array}$ & $\begin{array}{c}\mathrm{CCR} \\
{[\mathrm{wt} \%]}\end{array}$ & $\begin{array}{c}\mathrm{C} \\
{[\mathrm{wt} \%]}\end{array}$ & $\begin{array}{c}\mathrm{H} \\
{[\mathrm{wt} \%]}\end{array}$ & $\begin{array}{c}\mathrm{S} \\
{[\mathrm{wt} \%]}\end{array}$ & $\begin{array}{c}\mathrm{N} \\
{[\mathrm{wt} \%]}\end{array}$ & $\begin{array}{c}\mathrm{O} \\
{[\mathrm{wt} \%]}\end{array}$ & $\mathrm{H} / \mathrm{C}$ \\
\hline 980 & 900 & 15.7 & 87.0 & 12.0 & 0.26 & 0.45 & 0.22 & 1.66 \\
\hline
\end{tabular}

\section{Results and Discussion}

It is well known, reaction temperature is an important parameter for heavy oil cracking, which has significant influence on the reaction rate, product distribution and product quality. In this work, the effect of reaction temperature on VR pyrolysis under millisecond level was investigated.

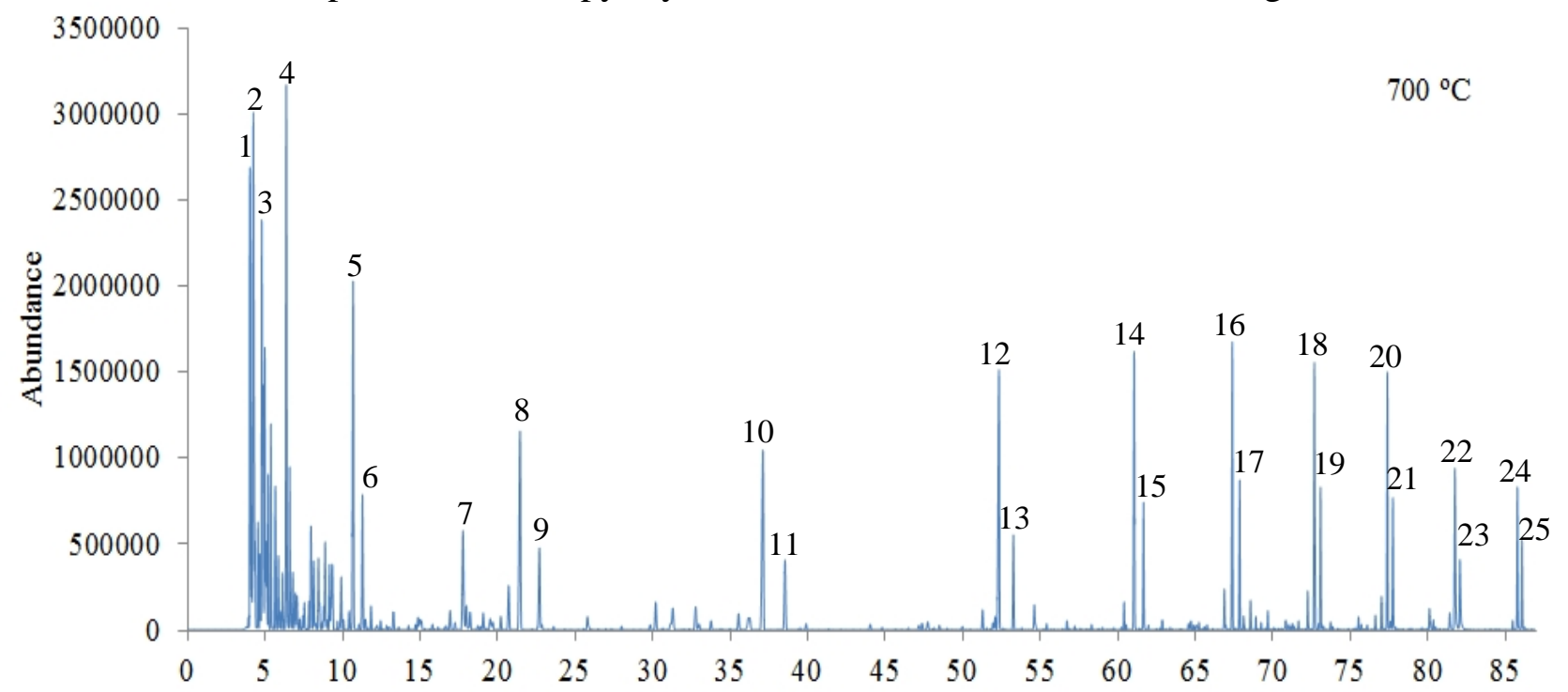

Fig. 1 Py-GC/MS chromatograms from millisecond pyrolysis of Shengli VR at $700{ }^{\circ} \mathrm{C}$

Table 2. Typical pyrolysis products of Shengli VR by Py-GC/MS.

\begin{tabular}{cccc|cccc}
\hline No & Name of compound & Formula & type & No & Name of compound & Formula & type \\
\hline 1 & Propene & $\mathrm{C}_{3} \mathrm{H}_{6}$ & Olefin & 14 & 1-Undecene & $\mathrm{C}_{11} \mathrm{H}_{22}$ & Olefin \\
2 & Butene & $\mathrm{C}_{4} \mathrm{H}_{8}$ & Olefin & 15 & Undecane & $\mathrm{C}_{11} \mathrm{H}_{24}$ & Paraffin \\
3 & 1-Pentene & $\mathrm{C}_{5} \mathrm{H}_{10}$ & Olefin & 16 & 1-Dodecene & $\mathrm{C}_{12} \mathrm{H}_{24}$ & Olefin \\
4 & 1-Hexene & $\mathrm{C}_{6} \mathrm{H}_{12}$ & Olefin & 17 & Dodecane & $\mathrm{C}_{12} \mathrm{H}_{26}$ & Paraffin \\
5 & 1-Heptene & $\mathrm{C}_{7} \mathrm{H}_{14}$ & Olefin & 18 & 1-Tridecene & $\mathrm{C}_{13} \mathrm{H}_{26}$ & Olefin \\
6 & Heptane & $\mathrm{C}_{7} \mathrm{H}_{16}$ & Paraffin & 19 & Tridecane & $\mathrm{C}_{13} \mathrm{H}_{28}$ & Paraffin \\
7 & Toluene & $\mathrm{C}_{7} \mathrm{H}_{8}$ & Aromatic & 20 & 1-Tetradecene & $\mathrm{C}_{14} \mathrm{H}_{28}$ & Olefin \\
8 & 1-Octene & $\mathrm{C}_{8} \mathrm{H}_{16}$ & Olefin & 21 & Tetradecane & $\mathrm{C}_{14} \mathrm{H}_{30}$ & Paraffin \\
9 & Octane & $\mathrm{C}_{8} \mathrm{H}_{18}$ & Paraffin & 22 & 1-Pentadecene & $\mathrm{C}_{15} \mathrm{H}_{30}$ & Olefin \\
10 & 1-Nonene & $\mathrm{C}_{9} \mathrm{H}_{18}$ & Olefin & 23 & Pentadecane & $\mathrm{C}_{15} \mathrm{H}_{32}$ & Paraffin \\
11 & Nonane & $\mathrm{C}_{9} \mathrm{H}_{20}$ & Paraffin & 24 & 1-Hexadecene & $\mathrm{C}_{16} \mathrm{H}_{32}$ & Olefin \\
12 & 1-Decene & $\mathrm{C}_{10} \mathrm{H}_{20}$ & Olefin & 25 & Hexadecane & $\mathrm{C}_{16} \mathrm{H}_{34}$ & Paraffin \\
13 & Decane & $\mathrm{C}_{10} \mathrm{H}_{22}$ & Paraffin & & & & \\
\hline
\end{tabular}


Figure 1 shows the ion chromatograms from millisecond pyrolysis of Shengli residue at $700{ }^{\circ} \mathrm{C}$. Table 2 lists some typical components of pyrolysis products according to the carbon numbers from 3 to 16. It can be found that in the millisecond pyrolysis process, $n$ - $\alpha$-olefins are the major products, which is conforming to the free radical theory[5].

One drawback of the Py-GC/MS apparatus is that it did not allow the product collection, thus the exact products yield could not be determined. However, because of the chromatographic peak area for a compound is in proportion to its yield, it is able to have a primary estimate of the yield changes through the comparison of the chromatographic peak areas obtained at different pyrolysis temperatures. The results are shown in Figure 2. Figure 2(a) shows that the total peak areas were increased monotonically as the increase of pyrolysis temperature from $600{ }^{\circ} \mathrm{C}$ to $800{ }^{\circ} \mathrm{C}$, which indicates more heavy oil were cracked into light fractions under higher temperatures.
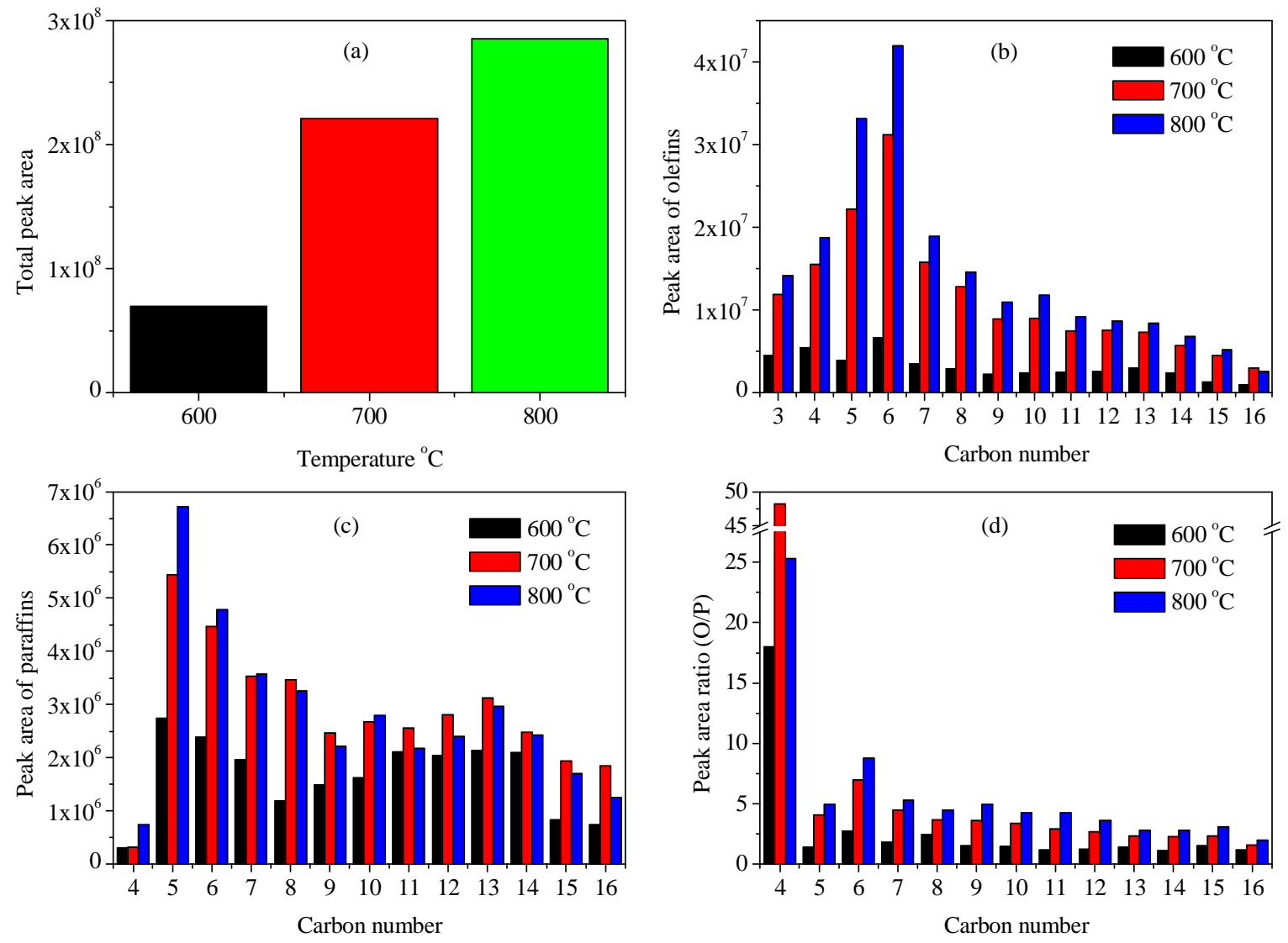

Fig. 2 Effects of pyrolysis temperature on the peak area of olefins and alkanes

Figure 2(b) presents the distribution of olefins according to the carbon number. The peak areas of olefins were all increased sharply first, especially at $700{ }^{\circ} \mathrm{C}$ and $800{ }^{\circ} \mathrm{C}$, and then decreased gradually with the growth of the carbon number. The maximum values were all obtained at $\mathrm{C}_{6}$ for different temperatures. When the pyrolysis temperature increased from $600{ }^{\circ} \mathrm{C}$ to $700{ }^{\circ} \mathrm{C}$, the peak area of olefins from $\mathrm{C}_{3}$ to $\mathrm{C}_{16}$ all showed a significant rising; however, as the temperature further went up to $800{ }^{\circ} \mathrm{C}$, the increase became lower. Figure 2(c) shows the variation of peak area of alkanes with pyrolysis temperature. There are two peaks for different temperatures. The maximum values were all obtained at $\mathrm{C}_{5}$, which are higher than the second peak values at $\mathrm{C}_{13}$. When the pyrolysis temperature increased from $600{ }^{\circ} \mathrm{C}$ to $700{ }^{\circ} \mathrm{C}$, the peak areas of $\mathrm{C}_{5}-\mathrm{C}_{16}$ alkanes were all increased significantly, due to the further cracking of high-boiling point fractions. However, as the further increase of the pyrolysis temperature, the cracking of alkanes higher than $\mathrm{C}_{7}$ was also enhanced, which can be inferred from the increasing of peak areas of $\mathrm{C}_{4}-\mathrm{C}_{6}$ alkanes and the decreasing of peak areas of alkanes over $\mathrm{C}_{7}$. Thus, it can be inferred the optimal pyrolysis temperature is approximately $700{ }^{\circ} \mathrm{C}$ in this study. 
The peak area ratios of olefins to paraffins with different carbon numbers were shown in Figure 2(d). As the propane was not detected in this study, the values for $\mathrm{C}_{3}$ were not shown. The ratios for $\mathrm{C}_{5}-\mathrm{C}_{16}$ hydrocarbons were all increased monotonically as the increase of pyrolysis temperature from $600{ }^{\circ} \mathrm{C}$ to $800^{\circ} \mathrm{C}$, while that for $\mathrm{C}_{4}$ hydrocarbons showed the maximum value at $700^{\circ} \mathrm{C}$. The yield of butenes was 18-48 times higher than the yield of butanes, which indicates that the high-temperature and short-residence time operation favors production of olefins over paraffins. This may be due to the higher temperatures enhanced the gas-phase cracking over liquid-phase cracking. Research found that hydrogen abstraction is predominant and much faster in liquid-phase cracking due to a higher reactant concentration. This will enhance the radical addition in the propagation step, leading to the reduction of olefins in the cracked products and the generation of high molecular weight compounds[3, 6-8].

Due to the high boiling of vacuum residue, the liquid-phase cracking is inevitable in the pyrolysis process of VR. Therefore, how to fast remove olefins from liquid phase became the key matter for raising the olefin yield and reducing the coke yield. The optimal method is to appropriately increase the reaction temperature to enhance the gas-phase cracking, as well as shortening the residence time to inhibit the saturation and cyclization reactions of olefins.

\section{Conclusions}

The high temperature and short residence time processing scheme could enhance the gas-phase cracking of residue, but too high a temperature would also lead to the overcracking of gasoline and diesel fractions. The optimal reaction temperature is approximately $700{ }^{\circ} \mathrm{C}$ in this study. Olefins were the dominant components in the gas products, especially under higher temperatures. $\mathrm{C}_{6}$ is the most abundant class in olefins product, while $\mathrm{C}_{5}$ is the most abundant class in paraffins product. The yield of butenes was 48 times higher than the yield of butanes at $700{ }^{\circ} \mathrm{C}$.

\section{Acknowledgements}

This work was financially supported by the National Natural Science Foundation of China (21576293), the Natural Science Foundation of Shandong Province (BS2015NJ006), the China Postdoctoral Science Foundation (2014M560589), and the Fundamental Research Funds for the Central Universities (15CX02020A and 15CX05044A).

\section{References}

[1] J.B. Joshi, A.B. Pandit, K.L. Kataria, R.P. Kulkarni, A.N. Sawarkar, D. Tandon, Y. Ram, M.M. Kumar, Ind. Eng. Chem. Res. Vol. 47 (2008), p. 8960-8988.

[2] A.N. Sawarkar, A.B. Pandit, S.D. Samant, J.B. Joshi, Can. J. Chem. Eng. Vol. 85 (2007), p. 1-24.

[3] G. Wu, Y. Katsumura, C. Matsuura, K. Ishigure, J. Kubo, Ind. Eng. Chem. Res. Vol. 35 (1996), p. 4747-4754.

[4] K. Vafi, W.C. McCaffrey, M.R. Gray, Energy Fuels, Vol. 26(2012), p. 6292-6299.

[5] B.S. Greensfelder, H.H. Voge, G.M. Good, Ind. Eng. Chem. Vol. 41 (1949), p. 2573-2584.

[6] M.R. Gray, W.C. McCaffrey, Energy Fuels, Vol. 16 (2002), p. 756-766.

[7] T.J. Ford, Ind. Eng. Chem. Vol. 25 (1986), p. 240-243.

[8] Y.V. Kissin, Ind. Eng. Chem. Res. Vol. 26 (1987), p. 1633-1638. 